\title{
The Importance of Resilience: Family, School, Community Size Predictions
}

\author{
Burcu Keskin (Corresponding author) \\ Osmangazi Counseling and Research Center, Bursa, Turkey \\ E-mail: burcucankeskin@gmail.com \\ Figen Akca \\ Department of Psychological Counseling and Guidance, \\ Faculty of Education, Uludağ University, Bursa, Turkey \\ E-mail: figen_akca@hotmail.com
}

\begin{abstract}
Resilience refers to the ability of successful adaptation and overcoming negative conditions successfully in spite of the challenges of a difficult situation; in terms of diseases, economic difficulties, violence and stress caused by modern life, it is an important issue. It is a necessity to raise resilient children who are prepared against difficulties and risks because it is not possible to eliminate all difficult and risky situations. Children live in a socio-ecological environment, so resilience develops in interaction with other elements in the environment. In this study, it is aimed to emphasize the dynamic structure and importance of resilience concept, to discuss resilience development within the context of family, school, society, culture and to focus on what can be done in order to raise resilient children. Under the scope of the research, articles and books that can be accessed as full text was examined by searching for keywords such as "resilience", "risk factors", "protective factors".
\end{abstract}

Keywords: Resilience, risk factors, protective factors

DOI: $10.7176 / \mathrm{JSTR} / 5-4-18$

\section{Psikolojik Sağlamlığın Önemi: Aile, Okul, Toplum Boyutunda Öngörüler}

\begin{abstract}
Özet
Zorluklar karşısında güçlü kalabilmek, risklere rağmen gelişmeye devam edebilmek anlamına gelen psikolojik sağlamlık kavramı, hastalıklar, ekonomik zorluklar, şiddet olayları ve modern hayatın yarattığı stres düşünüldügüunde son derece önemli bir konu olarak karşımıza çıkmaktadır. Tüm zorlu ve riskli durumları ortadan kaldırmak mümkün olamayacağı için zorluk ve risklere karşı hazırlıklı, psikolojik olarak sağlam çocuklar yetiştirmek bir gerekliliktir. Çocuklar sosyo-ekolojik çevre içinde yaşamlarını sürdürürler, dolayısıyla psikolojik sağlamlıkları da çevredeki diğer unsurlarla etkileşim halinde gelişir. Buradan hareketle bu derleme çalışmasında psikolojik sağlamlık kavramının dinamik yapısını ve önemini vurgulamak, aile, okul, toplum, kültür gibi bağlamlar içinde psikolojik sağlamlık gelişimini ele almak ve psikolojik olarak sağlam çocuklar yetiştirebilmek adına yapilabileceklere odaklanmak amaçlanmaktadır. Bu amaçla çeşitli veri tabanlarında "psikolojik sağlamlık", "risk faktörleri”, "koruyucu faktörler" anahtar kelimeleri kullanılarak literatür taraması yapılmış ve tam metin olarak ulaşılabilen makale ve kitaplar gözden geçirilmiştir.
\end{abstract}

Anahtar Sözcükler: Psikolojik sağlamlık, risk faktörleri, koruyucu faktörler

\section{Giriș}

İçinde bulunduğumuz yüzyılda her saniye yeni bir gelişmeye tanık olmaktayız. Tanıklık ettiğimiz tüm bu gelişmelere rağmen hala dünyada ve ülkemizde birbirinden güç, bireylerin yaşamları ve gelişimleri 
üzerinde yıkıcı etkileri olan olaylarla karşılaşmaya da devam etmekteyiz. Ekonomik zorluklar, hastalıklar, doğal afetler, iklim değişiklikleri, kazalar, şiddet ve terör olayları gibi faktörler insan hayatını zorlamakta ve bu tür olaylar doğrudan bizlerin başına gelmese ve hatta yakınımızda gerçeklemese bile 21. yüzyıl dünyasında televizyon ve internet yoluyla birçoğuna maruz kalmaktayız (Prince- Embury ve Saklofske, 2014). Tüm bunların yanında günlük hayatın doğasından ortaya çıkan zorluklar ve stres, sevilen birinin kaybı, ilişkilerdeki problemler, yüksek başarı beklentisi gibi faktörler de devreye girince bireylerin bütün bu olumsuzluklarla baş edebilmeleri, gelişmeye devam edebilmeleri ve geleceğe umutla bakabilmeleri için fiziksel olduğu kadar psikolojik olarak da sağlam olmaları gerekmektedir. Psikolojik sağlamlık kavramı uzun yıllardır psikoloji, psikiyatri ve psikolojik danışmanlık gibi alanların çalışma konusudur.

Anne babalar çocuklarını her türlü tehlikeden koruyabildikleri ve çocuklarının herhangi bir zorluk, başarısızlık ve hayal kırıklığı ile karşılaşmadıkları bir dünya hayal ederler. Böyle bir dünya kulağa ne kadar hoş gelse de gerçekçi değildir. Hayatımızda her zaman tamamen ortadan kaldıramadığımız çeşitli risk faktörleri olacaktır. Ancak tüm bu hayallerimiz gerçekleşmiş olsaydı bile bu durumun, çocuklarımız için gerçekten yararlı olup olmayacağı tartışmaya açık bir konudur. Bütün olumsuz durumlardan izole edilmiş bir çocuk, güç bir durumla baş edebilmenin memnuniyetini yaşama ve kendini yeterli hissetme şansını elde edememiş olur. Bu nedenle amacımız bütün olumsuz durumlardan çocuklarımızı izole etmek ve tamamen savunmasız çocuklar yetiştirmek değil hayatta karşılarına çıkan engelleri aşabilecek, zorluklarla baş edebilecek güçte çocuklar yetiştirmek olmalıdır (Gingsburg ve Jablow, 2006; Masten, 2014). Bununla birlikte psikolojik sağlamlığı yüksek çocukların anne baba olduklarında kendi çocuklarının psikolojik sağlamlık gelişimine destek olma ihtimalleri düşünüldügünnde toplumsal bir gelişmenin de ortaya çıkacağı söylenebilir. Bütün bu nedenlerle mevcut çalışmanın amacı, psikolojik sağlamlık kavramını aile, okul ve sosyal-kültürel bağlamlar içinde ele almak ve psikolojik sağlamlığ 1 yüksek çocuklar yetiştirebilmek adına atılabilecek adımlara odaklanmaktır.

Psikoloji bilimi, İkinci Dünya Savaşı'nın sonlanmasının ardından daha çok iyileşme süreciyle ilgilenen bir bilim dalı olmuş ve insan gelişiminde meydana gelen zorlukları düzeltmeye odaklanmıştır. Psikolojinin alt alanlarından biri olan pozitif psikoloji yaklaşımı geçmiş dönem çalışmalarında yalnızca patolojiye odaklanılmasını ve yaşamı yaşamaya değer kılan olumlu özelliklerin göz ardı edilmesini eleştirmiştir. Psikoloji biliminin sadece patoloji, zayıflıklar ve ruhsal bozuklukları çalışmasını değil aynı zamanda güç, erdem ve psikolojik sağlamlık üzerine de çalışması gerektiğinin, tedavinin amacının sadece bozuk olanı düzeltmek değil, aynı zamanda en iyiyi desteklemek olduğunun altını çizmiştir (Seligman ve Csikszentmihalyi, 2000). Dolayısıyla pozitif psikoloji riskten ziyade psikolojik sağlamlık üzerinde çalışmayı hedeflemektedir.

Psikolojik sağlamlık kavramı ile ilgili çalışmalar, 1970'li yıllarda dezavantajlar ve ailede ruhsal hastalık görülme durumuna göre yüksek risk altında kabul edilen çocuklarla yapılan ve hastalı̆ga giden yolda neyin etkili olduğunu anlayarak doğru tedavi yöntemleri geliştirmeyi hedefleyen çalışmalardan doğmuştur. Bu çalışmalar sırasında araştırmacılar bazı çocukların tüm zor ve riskli koşullara rağmen gelişmeye devam ettiklerini fark etmişler ve böylece yeni bir çalışma alanına öncülük etmişlerdir (Anthony, 1974; Garmezy, 1974; Murphy \&Moriarty, 1976; Rutter, 1979; Akt. Masten ve Coatsworth, 1998). 70'li yıllardan başlanarak halen çalışılmaya devam edilmesi kavramın önemini ortaya koymaktadır. Psikolojik sağlamlığın ülkemizde de özellikle son yıllarda artan bir ilgiye sahip olması, bu yönde bir ihtiyacın olduğunu düşündürmektedir (Akar, 2018; Gürgan, 2006; Kurtoğlu, 2013; Ünüvar, 2012).

Masten, Best ve Garmezy (1990, s. 426) psikolojik sağlamlık kavramını "zorlayıcı ve tehdit edici koşullara ragmen başarılı bir adaptasyon süreci, kapasitesi ve sonucu" olarak tanımlamışlar ve literatürde şu üç durumu açıklamak için kullanıldığını belirtmişlerdir: 1) yüksek riske ragmen iyi sonuçlar elde etmek, 2) tehdit altında sürdürülebilir yetkinlik, 3) yaşanan travmadan sonra iyileşebilme. Benzer şekilde Fraser, Richman ve Galinsky (1999) psikolojik sağlamlık kavramının olağanüstü koşullara uyum sağlayabilen, zorluklara rağmen olumlu ve beklenmedik sonuçlar elde edebilen bireyleri tanımlamak için kullanıldığını ifade etmişlerdir.

$\mathrm{Bu}$ tanımlardan da anlaşılacağı üzere psikolojik sağlamlıktan bahsedebilmek ve bir bireyi 'sağlam (resilient)' olarak nitelendirebilmek için iki temel unsurun mutlaka bulunması gerekmektedir. Bunlar, bireyin hayatında normal gelişimini aksatacak potansiyele sahip, görünür, dikkate değer bir risk faktörünün olması ve bireyin bu risk faktörüne rağmen içinde bulunduğu ortam ve gelişimsel aşamaya göre kendisinden beklenen pozitif uyumu ya da gelişimsel görevi yerine getirebilmesidir (Masten ve Coatsworth, 1998). Herhangi bir tehdit edici duruma maruz kalmayan ancak başarılı ve uyumlu olan bireyler için yalnızca 'yeterli' kavramı kullanılabilir (Luthar ve Cicchetti, 2000; Masten ve Reed, 2002). 


\section{Yöntem}

$\mathrm{Bu}$ derleme çalışmasında literatür inceleme yöntemi kullanılmıştır. Çalışma kapsamında ilk olarak anahtar sözcükler "psikolojik sağlamlık", "risk faktörleri", "koruyucu faktörler" olarak belirlenmiştir. Daha sonra belirlenen bu anahtar kelimeler çeşitli veri tabanlarında Türkçe ve İngilizce olarak kullanılarak literatür taraması yapılmışıı. Bu kapsamda tam metin olarak ulaşılabilen makale ve kitaplar gözden geçirilmiştir. Çalışmalar, başlık, özet ve içindekiler kısımları incelenerek çalı̧̧ma amacına uygun olarak seçilmiştir. Seçilen makale ve kitaplar incelenerek çalışmanın başlıkları şu şekilde belirlenmiştir: Psikolojik sağlamlığın yapısı ve gelişimi, psikolojik sağlamlık modelleri, koruyucu faktörler ve risk faktörleri, aile, okul, toplum ve kültür boyutunda psikolojik sağlamlık.

\section{Psikolojik Sağlamlığın Yapısı ve Gelişimi}

Erken dönem psikolojik sağlamlık çalışmalarında (Anthony, 1974; Akt. Fleming ve Ledogar, 2008; Pines, 1975; Akt. Winders, 2014) tüm zorluk ve risk faktörlerine ragmen gelişim görevlerini yerine getirebilen çocukların 'zarar görmezlik', 'incinmezlik' ya da ‘yenilmezlik' gibi sıra dı̧̧ı özelliklere sahip oldukları kabul edilmiştir. Masten (2001) ise psikolojik sağlamlığın, olağanüstü ve nadir özelliklerden değil sıradan kaynak ve süreçlerden meydana geldiğini ve temel uyum sistemlerinin iyi çalışır durumda olmasının sonucu olarak ortaya çıktığını savunmuştur. Bu temel sistemler ise bağlanma sistemi, stress yanıt sistemi, öz düzenleme sistemi, motivasyon sistemi, öğrenme sistemi, aile sistemi, okul sistemi, akran sistemi, ve kültürel-toplumsal sistemler olarak sinıflanmıştır (Masten ve Obradovic, 2006).

Urie Bronfenbrenner (1979), ekolojik sistemler teorisi ile bir çocuğun gelişiminin, çocuğun kendisinin sahip olduğu nitelikler ile çevresindeki niteliklerin etkileşimi sonucu olduğunu dile getirmiş ve gelişim üzerinde çevrenin etkisini vurgulamıştır. Çocuğu merkeze alarak ertafında dört temel sistem belirlemiş ve bu sistemlerin kaçınılmaz olarak çocuğun hayatının her alanında birbirleriyle etkileşimde bulunduklarını ifade etmiş̧ir. Bunlar, mikrosistem, mezosistem, ekzosistem ve makrosistemdir.

Mikrosisteme örnek olarak bireye en yakın olan aile ve okul gibi kurumlar gösterilebilir. Mezosistem ise çocuğun içinde olduğu farklı mikrosistemlerin bir araya gelmesiyle oluşan daha geniş bir sistemdir. Örnek olarak aile ve okul arasındaki ilişkiyi ya da aile ve çocuğun arkadaş grubu arasındaki ilişkiyi vermek mümkündür. Ekzosistem ise çocuğun doğrudan içinde bulunmadığı ancak gelişimi üzerinde dolaylı etkiye sahip unsurların yer aldığı bir üst sistemdir. Anne babanın iş ortamındaki olumlu/olumsuz durumların çocuğa yansıması bu sistemi somutlaştırmak adına örnek olarak kullanılabilir. Dördüncü ve en geniş sistem olan makrosistem ise çocuğa en uzak sistemdir ve kültürel yapı, değerler sistemi, politik ve ekonomik durumlar bu sistemin unsurlarıdır (Bronfenbrenner, 1979).

Benzer şekilde Ungar (2011) psikolojik sağlamlığa sosyo-ekolojik bir pencereden bakarak psikolojik sağlamlı̆̆ın çocuk ve sosyo-ekolojik çevresi arasındaki etkileşiminden oluşan dinamik bir süreç olduğunu, Masten (1994) ise psikolojik sağlamlığın risk faktörleri ve koruyucu faktörler adı verilen durumların etkileşimi yoluyla ortaya çıkan dinamik yapıya sahip bir özellik olduğunu ifade etmiş̧tir.

Psikolojik sağlamlığın yapısını ve gelişimini daha iyi anlayabilmek için psikolojik sağlamlık modellerine yer vermek uygun olacaktır.

\section{Psikolojik Sağlamlık Modelleri \\ 4.1 Telafi Edici Model}

Bu model, olumlu çıktı yani psikolojik sağlamlık üzerinde doğrudan etkileri olan risk faktörlerinin ve telafi edici faktörlerin (niteliklerin, kaynakların) bir birleşimini içerir. Bu model ile anlatılmak istenen, risk faktörlerinin ve telafi edici faktörlerin psikolojik sağlamlık üzerinde doğrudan etki yarattı̆̆ıdır. Telafi edici faktör risk faktöründen zit yönde etki ederek risk faktörünün etkisini nötrler. Telafi edici faktörün, risk faktörünün etkisinden bağımsız olarak sonuç üzerinde doğrudan etkisi söz konusudur (Garmezy, Masten ve Tellegen, 1984).

Masten ve meslektaşları (1988) bu modeli stress ve öz saygı değişkenlerinin yeterlik üzerindeki etkilerini örnek vererek açıklamışlardır. Stres risk faktörü, öz saygı da telafi edici faktör işlevi görmektedir ve her ikisinin de yeterlik düzeyi üzerinde doğrudan etkileri vardır. Bir değişkenin diğgerine göre daha yüksek olması yeterlik düzeyi üzerinde belirleyici olacaktır. Daha yüksek öz saygı seviyesi daha yüksek stress seviyesini telafi edecektir. Yüksek öz saygıya sahip çocuklar yüksek stress altında, daha düşük öz saygıya sahip ancak daha düşük strese maruz kalan çocuklara kıyasla daha fazla yeterlik gösterecektir.

$\mathrm{Bu}$ model rehberliğinde hazırlanan müdahale programları risk faktörünün ortaya çıkmasını önleme, risk durumunun etkilerini telefi edebilecek nitelikler kazandırma, kaynaklar ekleme amaçlarını taşımaktadır (Masten, 2014).

\subsection{Meydan Okuma Modeli}

$\mathrm{Bu}$ model, çok yüksek bir düzeydeki zorluğun olumsuz sonuçlara neden olacağını ancak orta düzeyde 
bir zorluğun bireyin baş etme becerilerini geliştireceğini, yeterliğini arttıracağını ifade eder (Garmezy ve diğ., 1984). Hart (1990), bir noktaya kadar olan stresin motivasyonu ve performansı arttırdı̆̆ını ancak giderek artan stress seviyesinin biyolojik enerji kaynağını tükettiğini ve performansta düșüşe neden olduğunu belirtmiştir. Sınavı için makul ölçüde stress yaşayan bir öğrenci için stress itici bir güç olabilir, başarmak için motivasyonu arttırabilir ve öğrenci daha iyi bir performans gösterebilir. Sürekli artan stress düzeyi ise ters yönde etki yaratabilir.

\subsection{Aracı Model}

Conger ve Conger (2002), bazı zorlukların çocuğun hayatına doğrudan zarar vermediğini ancak çocuğun hayatındaki önemli elementler üzerindeki etkileri yoluyla yani dolaylı olarak zarar verdiğini belirtmişler ve bu duruma örnek olarak 20. yüzyılın sonlarına doğru ortaya çıkan ekonomik krizin Iowa'da yaşayan çiflik ailelerini göstermişlerdir. Ekonomik zorluklar anne babanın ruh hallerinde, evlilik kalitelerinde olumsuz etkilere neden olmuş ve dolayısıyla etkili anne babalık becerilerine de olumsuz olarak yansımıştır.

Bu model temel alınarak hazırlanan müdahale programlarında risk faktörünün önlenememesi durumunda aracı rolü üstlenen faktöre destek sağlamak amaçlanır. Kriz esnasında anne babaları etkili ebeveynlik ile ilgili desteklemek bu model için bir örnektir (Masten, 2014).

\subsection{Moderator (Düzenleyici) Model}

$\mathrm{Bu}$ model kapsamında, riskle aktive olan moderator ve riskten bağımsız moderator olmak üzere iki tür moderator söz konusudur. Riskle aktive olan moderator, birey bir risk durumu ile karşılaştığında ortaya çıkmakta ve bireyi risk durumunun etkilerinden korumaktadır. Otomobillerdeki hava yastıkları ve insan bağışıklık sistemi bu yönde çalışmaktadır. Riskle aktive olan moderator yani hava yastığı tehdit anında devreye girerek bireyi olası etkilerden koruyabilir. Aynı şekilde insan bağısılık sistemi de bir tehditle karşılaştığında tehdit unsuruna karşı savaşarak bireyi hastalıklardan korumaktadır. Ancak hava yastığının tehdit anında değil de ihtiyaç olmadığında açılması ya da bağışıklık sisteminin kendine saldırması risk fakötürü olarak karşımıza çıkmaktadır (Masten, 2014).

İkinci moderator ise tehdit tarafından aktive edilmeyen ancak karşılaşılan risk faktörünün etkilerini arttıran ya da azaltan, halihazırda bireyde bulunan özelliklerdir (Masten, 2014). Garmezy ve meslektaşları (1984) bu modeli 'koruyucu faktör modeli' olarak ele alarak olumlu kişisel özelliklerin kişide mevcut olmasının riske karşı bir çeşit bağışıklık oluşturduğunu, risk faktörünün etkisini değiştirdiğini ve bu özelliklerin etkisinin risk karşısında daha güçlü olduğunu dile getirmiştir. Strese karş1 hassasiyeti daha yüksek olan bir kişi ile strese duyarlılı̆̆ 1 daha düşük oaln bir kişinin aynı stress faktörüne verdiği tepki farklı olacaktır (Masten, 2014).

\section{Koruyucu Faktörler ve Risk Faktörleri}

Psikolojik sağlamlık gelişiminde risk faktörlerinin ve koruyucu faktörlerin etkileşimin söz konusu olduğu (Masten, 1994) daha önce belirtilmişti. Bu bölümde ise literatürde adı geçen risk faktörlerine ve koruyucu faktörlere yer verilmiştir.

\subsection{Risk Faktörleri}

Risk faktörleri, yaşamımızdaki stres ve zarar görmemize neden olan durumlar, istenmeyen sonuçları yaşama olasılığımızı arttıran etkenler olarak tanımlanmaktadır (Masten, 1994). Bazen birden fazla risk faktörü bir arada bulunabilir ve birbirleriyle ilişki halinde daha ciddi sonuçlara yol açabilir. Masten, Morison, Tellegen ve Pellegrini (1990) bu duruma kümülatif risk adını vermişlerdir.

Literatürde adı geçen bireysel, ailesel ve çevresel risk faktörlerinden bazıları şunlardır: erken doğum (Bradley ve diğ., 1994), yoksulluk, doğal afetler, psikopatolojiye sahip bir ebeveynin olması (Masten, 2001), süreğen hastalıklar (McCubbin, Balling, Passin, Frierdich ve Bryne, 2002), ebeveyn kaybı (Lin, Sandler, Ayers, Wolchik ve Luecken, 2004), olumsuz yaşam olayları (Masten ve diğ, 1990).

\subsection{Koruyucu Faktörler}

Koruyucu faktörler ise risk durumunun etkisini azaltan veya ortadan kaldıran, istenmeyen sonuçların ortaya çıkma olasılığını azaltan ve sağlıklı uyum sürecini kolaylaştıran unsurlardır (Masten, 1994; Rutter, 1985). Risk faktörlerinde olduğu gibi koruyucu faktörler de bireyin kendisinden, ailesinden, içinde yaşadığı toplumdan, fiziksel çevresinden kaynaklanır (Werner, 1995). Bu faktörlere örnek olarak problem çözme becerileri (Werner, 1995), öz saygı ve öz yeterlik (Masten, 1994; Rutter, 1985), olumlu mizaç ve sosyal zeka (Rutter, 1985), özerklik (Benard, 1991), içsel motivasyon (Masten, 2001) aile bireyleriyle olumlu ilişki, öz düzenleme becerileri (Masten ve Coatsworth, 1998), olumlu akran ilişkileri (Criss, Pettit, Bartes, Dodge ve Lapp, 2002) gösterilebilir.

Masten, Best ve Garmezy 1990), anne babanın ya da bakım veren diğer yetişkinlerin çocuğun hayatındaki 
ilk koruyucu faktör olduklarını, kronik sıkıntı yaşayan çocukların, ilgili bir yetişkinle doyurucu ilişkiye sahip olduklarında yaşadıkları güçlüklerle daha iyi başa çıkabildiklerini, problemlerini etkili şekilde çözebildiklerini belirtmişlerdir. Aynı şekilde Masten ve Coatsworth (1998) da en az bir sevgi dolu ebeveynin ya da bakıcının varlığının psikolojik sağlamlığın gelişimine katkı sağladığının altını çizmişlerdir. Buradan hareketle, aile bireyleriyle ilişkinin koruyucu faktörler arasında bir adım öne çıktı̆̆ı söylenebilir. Bu durum, sevginin insanın ihtiyaç duyduğu en temel unsurlardan biri olduğu, birçok özelliğin sevgi ortamında gelişmesinin mümkün olduğu şeklinde yorumlanabilir.

Risk faktörlerinin birbiriyle olan ilişkisi koruyucu faktörler için de geçerli olabilir. Örneğin, öz düzenleme becerilerine sahip bir çocuk daha kolay arkadaş edinebilir, sağlıklı sosyal ilişkilere sahip olabilir (Alvord ve Grados, 2005), dürtülerini kontrol edebilen bir çocuk gereğinden fazla yemeyi önlemede daha başarılı olabilir ve bu durumun neden olabileceği sağlık sorunlarının da önüne geçebilir. Bir çocuğun hayatında koruyucu faktörler ne kadar erken desteklenmeye başlanmışsa o çocuğun psikolojik sağlamlık geliştirme olasıllı̆̆

Risk fakötleri ve koruyucu faktörlerin birbirinden tamamen bağımsız olarak düşünülemeyecekleri söylenebilir. Barankin ve Khanlou (2007) bu durumu şöyle bir örnekle açılamışlardır: Bir çocuğun her iki ebeveyne de sahip olması ve bir arada yaşaması genelde koruyucu bir faktör olarak kabul edilir ancak ebeveynlerden biri çocuğa ya da diğer ebveyne karşı fiziksel veya duygusal olarak istismarda bulunuyorsa o zaman bu durum koruyucu faktör olmaktan çıkarak risk faktörü halini alabilir.

Risk faktölerinin ve koruyucu faktölerin etkisi zaman içinde bireyin ailesi, arkadaşları, içinde yaşadığı toplum ile etkileşimi sonucunda değişime uğrayabilir (Barankin ve Khanlou, 2007; Masten ve Barnes, 2018).

Alvord ve Grados (2005) bütün çocukların bir potansiyelle doğduklarını ve aldıkları destek yardımıyla psikolojik sağlamlığı öğrenebileceklerini ve arttırabileceklerini ifade etmişlerdir. Ayrıca psikolojik sağlamlığı geliştirmek riski ortadan kaldırmaktan daha kolay ve ekonomiktir. Bir çocuk şu anda herhangi bir zorlukla baş etmek zorunda değilse bile psikolojik sağlamlığını destekleyerek ileride karşılaşması olası risklere karşı hazırlıklı olmasında yardımcı olmak mümkündür (Beyond Blue, 2017). Bu durum 'önleme' kavramını akla getirmektedir. Önleme, gelecekte karşılaşılması olası istenmeyen durumları engellemek adına şimdiden eyleme geçmektir (Albee ve Ryan, 1998). Clauss-Ehlers ve Weist (2004) de bireylerin güçlü yönlerinin desteklenmesi yönünde adımlar atılmasının problemlerin kriz haline gelmeden önlenebileceğini dile getirmişlerdir.

Son olarak 'psikolojik olarak sağlam' çocukların özelliklerine yer verilmesinin uygun olacağı düşünülmektedir. Brooks ve Goldstein (2001)'e göre psikolojik olarak sağlam çocuklar güçlü ve yeterli kendilik algısına sahiptirler. Güçlü yönlerinin, yeteneklerinin farkında olmakla beraber zayıf ve hassas noktalarını da kabul ederek kendileri için gerçekçi hedefler koyarlar. Etkili problem çözebilme ve karar verebilme becerilerine sahiptirler. Karşılaştıkları sorunları kaçınılması gereken zorluklar olarak değil mücadele edilecek firsatlar olarak görürler. Akranları ve yetişkinler ile etkili ilişki kurabilme becerilerine sahiptirler. İhtiyaç duydukları desteği uygun şekilde isteyebilirler.

İlerleyen bölümlerde psikolojik sağlamlık, aile, okul, toplum ve kültür boyutunda ele alınmış ve sağlamlı̆̆ı geliştirebilmek adına neler yapılabileceği üzerinde durulmuştur. En basit şekilde ifade etmek gerekirse psikolojik sağlamlığ 1 arttırabilmek için risk faktörlerini mümkün olduğunca azaltmamız ve koruyucu faktörleri de mümkün olduğunca arttırmamız gerekmektedir.

\section{Aile, Okul, Toplum ve Kültür Boyutunda Psikolojik Sağlamlık}

\subsection{Aile Boyutunda Psikolojik Sağlamlık}

Güçlü olabilmek ve psikolojik sağlamlık geliştirebilmek için çocukların koşulsuz sevgi, mutlak güvenlik duygusu ve en az bir yetişkinle sağlıklı, derin bir bağ kurmaya ihtiyaçları vardır (Masten ve Coatsworth, 1998). Buradan hareketle çocuğun hayatında daha fazla sağlıkl, yeterli ve destekleyici yetişkinin olmasının çocuğun yararına olduğunu ve yetişkinlerin rehberliğinde zorluklarla daha kolay baş edebileceğini söylemek mümkündür. İlişki kurmanın en önemli bileşeni olarak ise empati yeteneği gösterilebilir. Bir durumu başkasının gözünden görebildiğimizde o kişiye önemli olduğu mesajını iletiriz. Çocuklarımıza karşı empatik davrandığımızda onlar için güvenli bir alan oluşturmuş oluruz. Böylece herhangi bir problem yaşadıklarında rahatlıkla bize gelebilirler çünkü onları yargılamadan dinleyeceğimizi bilirler. Bununla birlikte çocuklar, empatiye yalnızca anlaşıldıkları ve saygı duyulduklarını hissedebilmek amacıyla ihtiyaç duymazar. Sağlıklı arkadaşlık ilişsileri kurabilmeleri, ilgili yetişkinler olabilmeleri için ebeveylerinin iyi birer rol model olmalarına ihtiyaçları vardır (Ginsburg ve Jablow, 2006). Burada dikkat edilmesi gereken husus, empatinin çocuklarımızla aynı şeyi düşündüğümüz ya da yaptıkları her şeyi onayladığımız değil, bunun yerine bakış açılarını anlayabildiğimiz ve durumları onların gözünden görebildiğimiz anlamına geldiğidir (Brooks ve Goldstein, 2001). Çocukları içtenlikle yargılamadan dinlemek ve anlamaya çalışmak söyleyeceğimiz 
sözcüklerden daha anlamlı olabilir.

Çocuklara yaşlarına uygun hikayeler okuyarak ve kendilerini karakter yerine koyarak düşünmelerine yardımcı olmak empati yeteneğini geliştirmek için yapılabilecek en basit uygulamadır. Günlük hayatta zor durumda olan ve bu zorlukla baş edebilen insanların neler yaşamış olabileceği üzerine düşünmek çocuklarda hem empati duygusunun gelişimini hem de psikolojik sağlamlığın gelişimini destekleyebilir. Werner (1993), başkalarına yardım etmenin çocuklarda empati, sorumluluk ve öz saygının gelişmesine yardımcı olduğunu dile getirmiş̧tir. $\mathrm{Bu}$ bağlamda çeşitli gönüllü projelere katılmak çocuğun empati yeteneğini geliştirebilir. Brooks (2013), benzer şekilde çocuklara içinde yaşadıkları çevreye katkıda bulunma firsatı verilmesinin onlarda sorumluluk bilincinin, şefkat duygusunun gelişimini sağlayacağını, verilen bu sorumluluğun çocuğun baş etme becerilerine güvenildiği mesajını ileteceğini ifade etmiştir.

Bir bireyin bulunduğu ortama uyum sağlayabilmesi, davranışlarını ortamın gerektirdiklerine göre ayarlayabilmesi anlamına gelen öz düzenleme yeteneği (Vohs ve Baumestier, 2004) bireysel koruyucu faktör olarak görev yapar ve psikolojik sağlamlığın yordayıcısıdır (Eisenberg ve Spinrad, 2004). Öz düzenleme becerisi; problem çözme yeteneği, eleştirel düşünme, uyum yeteneği, iletişim becerileri gibi birden fazla alt beceri grubunu bünyesinde barındırır (de laFuante, Zapata,Martinez-Vicente, Sander ve Crdelle-Eleuar, 2015). Bir çocuğun duygu, düşünce, dürtü, davranış kontrolü yapabilmesi çevreye pozitif uyum sağlamasını ve dolayısıyla mutlu, başarılı bir hayat sürmesini kolaylaştııır (Duckworth ve Seligman, 2005). Markette sıra beklemek, sinemada sessiz olmak gibi günlük hayatlarımızda karşılaştığımız farklı sosyal durumlar çocuklara öz düzenleme becerileri açısından model olmak amacıyla kullanılabilir. Sosyal düzene uymanın önemi ve uyulmadığı takdirde karşılaşılması muhtemel durumları tartışmak yararlı olabilir. Günlük işlerle ilgili planlar ve seçimler yapmasına şans vermek, yönlendirmeli oyunlar oynamak öz düzenleme becerilerinin gelişimine katkı sağlayabilir.

Karşılaștı̆ıııı tüm zorluk ve riskler her zaman olumsuz değildir. Aksine yönetilebilir düzeyde zorluk veya stres olumlu gelişmeye katkı sağlayabilir (Masten, 2014). Tüm stres ve risk faktörlerini ortadan kaldırmak mümkün olmayacağı için ebeveynlere düşen görev çocuklara zorluklarla etkili, gerçekçi şekilde başa çıkabilme becerilerini öğretmektir. Ebeveynler çocuklarına sürekli olarak yapmaları gerekenleri söylemekten vazgeçmeli, alternatif çözümler üretmek için teşvik edici rolde olmalıdırlar (Brooks, 2013). Çocuklar üzerinde aşırı korumacı davranmak, onlar yerine bütün problemleri çözmek çocuklara yeteri kadar güvenmediğimiz, yeteri kadar iyi olmadıkları mesajını verir ve anne babalarına bağımlı olmaya devam ederler. Bazen çocuklar için yapılabilecek en değerli şey yollarından çekilmek, yeni deneyimler yaşama, kendi yeteneklerini tanıma firsatı vermek olabilir çünkü psikolojik sağlamlığın temel yapı taşlarından olan yeterlik, deneyim yoluyla kazanılan, kümülatif bir özelliktir. Çocuklarda yeterlik duygusunu geliştirebilmek için deneyim firsatı yaratmanın yanı sıra seçim yapma, seçimlerin sorumluluğunu üstlenme firsatı verildiğinde çocuklar durumlar üzerinde kontrolü olduğunu hissettme şansı bulurlar, kendi yeteneklerine güvenirler, hatalarından öğrenir ve nihayetinde daha bağımsız olurlar. Farklı durumlara özgü rol oynama bir çocuğun yeterliğini geliştirmek için seçilebilecek eğlenceli bir yol olabilir (Brooks, 2013; Gingsburg ve Jablow, 2006). Burada bahsedilenler psikolojik sağlamlığın meydan okuma modeli (Garmezy ve diğ., 1984) ile örtüşmektedir.

Psikolojik olarak sağlam çocukların ebeveylerinin sahip oldukları özelliklere yer vermenin yararlı olacağı düşünülmektedir. Böylece ebeveynler kendilerini değerlendirme firsatı bulabilirler. Brooks ve Goldstein (2001), psikolojik olarak sağlam çocukların ebeveynlerinin özelliklerini şu şekilde belirtmişlerdir:

- Empatiktirler

- Aktif ve yargilamadan dinleyebilme becerilerine sahiptirler

- Çocuklarını oldukları gibi kabul ederek onlara gerçekçi hedefler koymalarında yardımcı olurlar

- Çocuklarına, hataların yeni deneyimler kazanabilecekleri birer firsat olduğunu anlamalarında yardımci olurlar

- Cocuklarının problem çözme ve karar verme becerilerini öğrenmesinde yardımcı olurlar

- Öz disiplini ve öz değeri teşvik edecek şekilde disiplin yöntemleri geliştirirler

- Çocuklara içinde yaşadıkları doğaya ve topluma katkıda bulunma firsatları sağlayarak sorumluluk, şefkat ve sosyal vicdanı geliştirmelerinde yardımcı olurlar.

Anne babaların dikkatli davranmaları gereken bir diğer konu çocukların duygu, düşünce ve değerleri üzerinde azımsanamayacak etkiye sahip olan medyadır. Medyanın çocuklar üzerinde olumlu etkileri olabileceği gibi zarar verici etkisi de olabilir. Yetişkinler olarak çocuklarımıza medya mesajları hakkında eleştirel düşünebilmeyi öğretmeli ve sağlıklı beden algısı üzerinde tartışmalı, televizyonda, dergilerde, sosyal paylaşım ortamlarında gördükleri kadın ve erkek imajının normu yansıtmadığını, üzerinde çokça oynanmış olduğunu fark etmelerinde yardımcı olmalıyız (Barankin ve Khanlou, 2007). 
Buraya kadar bahsedilen olumlu ve destekleyici ilişkiler, empati, öz düzenleme, problem çözme becerileri gibi unsurlar psikolojik sağlamlığın telafi edici modeli kapsamında değerlendirilebilir. Çocuklarla sıcak ve destekleyeici ilişkiler kurarak, ilişkilerde empatik davranarak ve empati becerisini öğreterek, öz düzenleme, problem çözme becerilerini geliştirerek yeterliğe katkı sağlanabileceği, diğer bir deyişle psikolojik sağlamlığı doğrudan etkileyebilecek yeni nitelikler kazandırılabileceği söylenebilir.

\subsection{Okul Boyutunda Psikolojik Sağlamlık}

Okul, çocukların en çok vakit geçirdikleri ortamlardan biridir ve dolayısıyla okulların psikolojik sağlamlığın gelişimi üzerinde önemli rol oynadığını söylemek zor değildir. Ringeise, Henderson ve Hoagwood (2003) okulu, okul bölgesi, toplum ve ulusal politikalar gibi kendinden daha geniş birçok farklı sistemle etkileşime giren ve değişen dinamik bir sistem olarak ele alırken Rutter (1985) da okulları çocukların öz saygıları ve yeterliklerini arttıracak ve dolayısıyla psikolojik sağlamlık gelişimine katkıda bulunacak deneyimler sunan bir kurum olarak ele almaktadır.

Pek çok çalışmada öğretmenlerin, okul yöneticilerinin, okul psikolojik danışmanlarının, olumlu okul ikliminin yüksek risk altında bulunan çocukların hayatında koruyucu faktör rolünü üstlendikleri belirtilmiştir (Benard, 1995; Condly, 2006; Masten ve diğ., 1990; Masten, Herbers, Cutuli ve Lafavor, 2008). Bu bağlamda okul kapsamı içinde yer alan, öğretmen, yönetici, psikolojik danışman, öğretim şekli gibi unsurların psikolojik sağlamlığa etkileri üzerinde durulmuş ve okulda psikolojik sağlamlığı desteklemek adına izlenebilecek stratejilere yer verilmiştir.

Çocuklar okulları güvenli bir ortam, öğretmenleri de onların iyi oluşlarını önemseyen yetişkinler olarak gördüklerinde okula bağlılıkları artar ve öğrenmek onlar için zevkli bir iş halini alır (Ginsburg ve Jablow, 2006) bu sayede öğretmenler, öğretme becerileri ile öğrencinin özgüvenlerine, öz yeterliklerine katkıda bulunmanın yanı sıra, elde etme motivasyonu da sağlayabilirler (Masten, 2014).

Hill ve Hawk (2000), öğretmenlerin öğrencileriyle kurabilecekleri etkili bir ilişkinin yolunun öğrencilerine ve onların kültürlerine saygı göstermek, adil ve sabırlı olmak, öğrencileriyle birlikte etkinliklere katılmak, kendi duygu, düşünce ve başarısılıklarını paylaşmaktan geçtiğini belirtmiştir. Brooks ve Goldstein (2001) ise etkili öğretmenleri, öğrencileri üzerinde yaşam boyu süren etkileri olduğunun farkında olan, tüm öğrencilerin başarılı olmayı arzuladığına inanan, eğer bir öğrenci öğrenemiyorsa o öğrencinin ihtiyac1 doğrultusunda öğretme stilini düzenleyen, öğrencilerin sosyal ve duygusal ihtiyaçlarıyla ilgilenen, empatik olan, disiplini korkutma süreci olarak değil öğretme süreci olarak algılayan kişiler olarak tanımlamışlardır.

Smith Harvey (2007), psikolojik sağlamlık gelişimini destekleyen okulların hayata hazırlık niteliğinde akademik programları uyguladığını, uygun zorluğa sahip, yapılabilir düzeyde ödevler verdiğini, öğrencilerin birlikte çalışmalarını desteklediğini belirtmiştir. Benard (1995) ise psikolojik sağlamlık gelişimini destekleyen bir müfredatın ve öğretimin geniş bir öğrenme stilleri yelpazesine sahip olduğunun, öğrencinin güçlü yanlarına, ilgi alanlarına, deneyimlerine, problem çözme becerilerine odaklandığının altını çizmiştir.

İyi bir okulun öncelikle iyi bir yöneticiye sahip olması gerektiğini söylemek mümkündür. Öğrencilerin ihtiyaç duydukları desteğin sağlanabilmesi için öğretmenlerin de okul yöneticisinden ihtiyaç duydukları desteği görmeleri gerekmedktedir (Smith Harvey, 2007). Okul müdürleri, öğretmenlere fikirlerini açıklama, tartışma firsatları vererek, iletişimde kalarak ve alınan kararlara öğretmenleri dahil ederek öğretmenlerin psikolojik sağlamlığına ve dolayısıyla öğrencilerin psikolojik sağlamlıklarına katkıda bulunabilirler (McLauhlin ve Talbert, 1993).

Öğrencilerin psikolojik sağlamlıkları için önemli olan bir diğer aktör ise okul psikolojik danışmanıdır. Williams ve arkadaşları (2016) yaptıkları çalışmada, öğrenciler tarafından kolaylıkla ulaşılabilen, ilgili, ögrencileri ellerinden gelenin en iyisini yapma yönünde cesaretlendiren ve umutlarını destekleyen bir psikolojik danışmanın koruyucu ve geliştirici bir unsur olduğunu belirtmişslerdir.

Akos ve Galassi (2008), psikolojik danışmanların güç temelli okıl danışmanlığı yaklaşımını benimseyerek, sorunlara ya da yetersizliklere değil de öğrencilerin güçlü yönlerine odaklanarak okulun genelinde olumlu gelişimi destekleyebileceklerini belirtmişlerdir. Ayrıca psikolojik danışmanlar tüm okul personelinin öğrencilerle olumlu ilişki kurmasına rehberlik ederek (Masten, 2014), çocuk hakları konusunda duyarlık kazanma konusunda yardımcı olarak (Theron, Liebenberg ve Malindi, 2014) ve psikolojik sağlamlık ile ilgili araştırma bulgularını okul personeliyle paylaşarak (Brooks ve Golstein, 2001) öğrencilerin psikolojik sağlamlıklarına katkıda bulunabilirler.

Okulların, özellikle risk altındaki çocukların psikolojik sağlamlığını desteklemek adına uygulayabileceği risk odaklı stratejiler bulunmaktadır. Bunlardan biri okul başarısı için önemli risk faktörlerini tanımlamak ve bunlar üzerinde çalışmaktır. Okula hazırlık için yapılabilecek kapsamlı bir tarama ile nörogelişimsel gecikmeler ya da konuşma problemleri belirlenip bu doğrultuda iyileştirici, 
zenginleştirici programlar hazırlanabilir. Ayrıca yeterli beslenme imkanı olmayan düşük gelirli öğrenciler için dengeli beslenme imkanı sunarak birçok hastalığın önüne geçilebilir (Masten ve diğ., 2008). Okulda zorbalığı ya da ayrımcıllı̆ı azaltmaya yönelik programların uygulanması risk odaklı stratejilere bir diğer örnektir (Barankin ve Khanlou, 2007).

Ergenlik dönemindeki öğrencilere yönelik ve depresyonu önlemek amacıyla geliştirilen Penn Psikolojik Sağlamlık Programı (Penn Resiliency Program), öğrencilerin her gün karşılaştıkları stress faktörleriyle baş edebilmelerini, problemlere ilişkin gerçekçi düşünebilmelerini ve iyimserlik kazanabilmelerini amaçlamaktadır (Seligman, Ernst, Gillham, Reivich ve Linkins, 2009). Brunwasser, Gillham ve Kim (2009) yaptıkları meta analiz çalışmasında programın depresyonu önlemede, umutsuzluğu azaltmada etkili olduğu sonucuna ulaşmışlardır.

Botvin ve Griffin (2004) tarafindan geliștirilen Yaşam Becerileri Programı (The Life Skills Program) ortaokul öğrencileri için uyuşturucu kullanımını önlemeye yönelik bir programdır. Program öz düzenleme becerilerini, sosyal becerileri öğreterek bireysel ve sosyal yeterliği arttırmayı, böylelikle uyuşturucu kullanımına karşı direnç geliştirmeyi hedeflemektedir.

Diğer bir önemli strateği, olumlu gelişmeyi sağlayan kaynaklar veya nitelikler oluşturmaya odaklanmıştır. Risk altındaki birçok öğrenci için okullar, evlerine, mahallelerine kıyasla nispeten nitelik bakımından zengin bir ortam olarak görülebilir. Bu stratejiye yönelik olarak hazırlanacak müdahaleler, okul sonrası etkinlik programları, akran dayanışması ile ödevlere yardımcı olmayı içerir (Masten ve diğ., 2008).

Son olarak okulların, afet gibi acil durumlara hazırlık ve müdahale konusunda merkezi rol oynadıkları, bu gibi durumlar ile ilgili müdahale programları geliştirilerek ve sıklıkla prova edilerek öğrencilerin psikolojik sağlamlıklarına katkıda bulunabilecekleri söylenebilir (Masten, 2014).

\subsection{Toplum ve Kültür Boyutunda Psikolojik Sağlamlık}

Daha önce de belirtildiği gibi sağlığımız, iyi oluşumuz ve psikolojik sağlamlığımız yalnızca öz niteliklerimizden etkilenmez, çevresel ve toplumsal koşullar da birer etkendir. Hatta bir çocuk ne kadar fazla sıkıntıya maruz kalırsa psikolojik sağlamlığı üzerinde çevrenin kalitesinin önemi de bir o kadar artmaktadır (Ungar, Ghazinour ve Richter, 2013).

İçinde yaşadığımız kültür bizlerin neyi iyi, sağlıklı veya sağlam olarak algıladığımızı etkiler. Kültürler ayrıca bir çocuğun gelişim dönemlerindeki uyumunu değerlendirme kriterlerini, çocukların nasıl destekleneceği ve yaşamdaki zorluklarla nasıl başa çıkabilecekleri hakkında bizlere rehberlik eder (Masten, 2014). Yani bir çocuk büyürken içinde yaşadığ kültürel çevre tarafindan gelişiminin ve psikolojik sağlamlığının şekillendirildiği söylenebilir. Buradan hareketle bu bölümde toplumsalkültürel bağlamın unsurları olan din, hukuk, ekonomi, güvenlik gibi unsurların psikolojik sağlamlık ile ilişkileri ele alınmıştır.

Masten (2014), kültürün bir parçası olan dinlerin, yaşamın anlamı hakkında çeşitli görüşler sunduğunu, yaşamın bir anlamı olduğu inancının en zor şartlarda bireylere güç ve umut verdiğini, ilahi bir figür ile kurulan ilişkide fiziksel ayrılık söz konusu olmadığı için bireyin güvenlik duygusunu hissedebileceğini ve duygusal rahatlık yaşayabileceğini belirtmiştir. Koruyucu ve adaletli bir ilahi güce inanmanın zor şartlar altındaki bireye bu durumun geçici olduğu ya da şimdi bu zor duruma katlanmanın ileride bir ödüle ulaşmayı sağlayacağı düşüncesini verdiği ve böylelikle dayanma gücünü arttırdığı düşünülebilir. Kültür ve toplum, aile ve okul bağlamında olduğu gibi hem koruyucu faktör hem de problemlerin kaynağı ve risk faktörü olarak işlev görebilmektedir. Crawford, Wright ve Masten (2006), dini inanışların, kültürel geleneklerin insan gelişiminde koruyucu işlevleri olsa da yine kültürel ve dini nedenlerle insanlığa karşı suçların işlendiğini, bireylerin ayrımcılığa maruz kaldığını, savaşların çıktığını belirtmişlerdir (Akt. Masten, 2014). Burada ise dini kuruluşlara ve politika yapıcılara iş düştüğü söylenebilir. Bu kurumlar tarafindan toplumsal ayrımcıllı̆̆ ve şiddeti önlemek adına çeşitli adımların atılmasının, toplumsal barışı arttırmaya yönelik çalışmalar yapılmasının yararlı olacağ düşünülmektedir.

Makrosistem içindeki önemli bir unsur olan ekonomi, bireylerin psikolojik sağlamlık gelişimlerine destek olan ya da tehlikeye atan maddi ve psikososyal koşulları belirler (Seaman, McNeice, Yates, ve McLean, 2014). Wadddel ve Burton (2006) işin, maddi kaynaklara erişim, psikolojik sağlık ve sosyal katılım için hayati öneme sahip olduğunu, Black (2008) ise bir işe sahip olmanın bireysel sağlık ve refah üzerinde olumlu etki yarattığını belirtmiştir. Ancak iş, çalışanların omzuna aşırı yük bindirmemeli, risk faktörü haline gelmemelidir (Brinkley, Fauth, Mahdon ve Theodoropoulou, 2009).

Ülkemizde ekonomik sıkıntıların yaşandığı bu günlerde ekonomik koşulların psikolojik sağlamlık üzerindeki etkisinin daha fazla hissedildiği söylenebilir. Yeterli gelir elde edememe nedeniyle birçok ailenin yetersiz beslendiğini, çocuklarını okula gönderemediğini, sağlık problemlerini tedavi ettiremediğini her gün haberlerde duymaktayız. Bu durumun önüne geçmek adına yeni iş alanlarının 
yaratılmasının, gıda yardımlarının yapılmasının, ücretsiz sağlı taramalarının yapılmasının ve aile danışmanlığı hizmetlerinin arttırılmasının yararlı olacağı düşünülmektedir.

Önemli bir diğer husus da sosyal adalet ve hukuk olarak karşımıza çıkmaktadır. Ungar ve arkadaşları (2007), bireylerin kendi toplumlarında adil muamele görmelerinin koruyucu işlevi olduğunu belirtmişlerdir. Bu bağlamda cinsiyet eşitliğini desteklemek, farklı kültür ve geleneklere karşı hassaslık ve hoşgörüyü teşvik etmek, kaliteli sağlık hizmetlerine ve devlet okullarına erişimi sağlamak, bireylere topluma ait olduklarını ve saygı gördüklerini hissettirmek toplum ölçeğinde psikolojik olarak sağlam bireyler yetiştirebilmek için atılması gereken önemli adımlardır (Barankin ve Khanlou, 2007). Belediyeler ve halk eğitim merkezleri aracilığıyla ebeveynlere ve çocuklara yönelik sanat, spor, bilim etkinlikleri ve eğitim programları düzenlenerek psikolojik sağlamlıklarına katkı yapılabilir.

Wright ve Masten (2015), insan haklarına duyarlı bir toplumun, vatandaşların korunmasına yönelik yasaların, çocuk koruma politikalarının, barışçıl politikaların psikolojik sağlamlığı arttırma potansiyeline sahip olduğunu belirtmiştir.

Toplumsal boyutta psikolojik sağlamlık için bir diğer önemli unsur da afetlere, felaketlere hazırlık olarak karşımıza çıkmaktadır. Devletlere düşen rol çeşitli felaket senaryolarına hazırlıklı olmak, kapasitelerini bu yönde arttırmak ve vatandaşların güvenliğini en iyi şekilde sağlamaktır (Brown ve Westaway, 2011). Deprem kuşağında yer alan ve son yıllarda iklim değişikliği nedeniyle sel felaketlerinin gerçekleştiği ülkemiz için bu durum son derece önem arz etmektedir. Bu tür afetlere dayanıklı binaların, yolların yapılmasının, güvenli toplanma alanlarının oluşturulmasının, acil durum anında en kısa sürede olay yerine varabilmek adına ulaşım sistemlerinin en uygun şekilde inşa edilmesinin hayati önem taşıdığı söylenebilir.

\section{Sonuç ve Öneriler}

Dünyada ve ülkemizde her gün bireylerin fiziksel ve ruhsal sağlığını olumsuz etkileyen olaylar yaşanmaya devam ederken zorluklara rağmen gelişmeye devam etmek anlamına gelen psikolojik sağlamlık kavramı da güncelliğini ve önemini korumaktadır. Tüm risk durumlarını ortadan kaldırmak mümkün olamayacağı için riskli durumlara karşı hazırlıklı olmak gerekmektedir. Bu durum özellikle çocuklar için önem kazanmaktadır çünkü birçok olumsuzluktan etkilenmiş, gelişimi sekteye uğramış ya da yara almış yetişkinleri iyileştirmeye çalışmaktansa zorluklarla etkili şekilde başa çıkabilecek güçte çocuklar yetiştirmek hem daha kolay hem de daha etkilidir. Albee ve Ryan (1998) halk să̆lı̆̆ 1 konusunda önleyici çalışmalar yapmanın geleneksel tedavi yöntemlerine göre daha etkili olduğunu belirtmiştir. Bu bağlamda psikolojik sağlamlığı desteklemenin depresyonu tedavi etmekten daha kolay ve ekonomik bir yöntem olduğu söylenebilir.

Güçlü bir toplumun güçlü ve psikolojik olarak sağlam bireylerden oluştuğu göz önüne alındığında psikolojik sağlamlığ yüksek çocuklar yetiştirmenin toplumun yararına olacağı açıktır. Psikolojik olarak sağlam çocuklar yetiştirmek için ailelere, okullara ve toplumun tamamına büyük görevler düşmektedir. Ekolojik sistem içindeki diğer unsurlarla etkileşim halinde bir sistem olan ailenin sağlamllğ 1 , bireylerin psikolojik sağlamlığı üzerinde etkilidir ve geniş sosyal sistemler içinde aileyi destekleyecek uygulamalar geliştirilmelidir (Masten, 2014). Ailenin temiz içme suyu, yiyecek, barınma, eğitim, güvenlik gibi temel unsurlara erişiminin sağlanması bu bağlamda ele alınabilir. Bununla birlikte okullar aracılı̆̆ıla anne babaların etkili ebeveynlik, etkili iletişim, doğru disiplin yöntemleri ve psikolojik sağlamlık konularında eğitilmeleri yararlı olabilir.

Çocukların en çok vakit geçirdikleri yer olan okullar da psikolojik sağlamlık gelişimi için önemlidir. Rehberlik servisleri aracıllğıyla, önleyici rehberlik kapsamında psikolojik sağlamlığı destekleyen çalışmalar yapılabilir. Ayrıca okullar resim, müzik, drama, spor gibi aktivitelere erişimi ve katılımı sağlayarak öğrencilerin psikolojik sağlamlıkları üzerinde olumlu etki yaratabilirler çünkü bu tür etkinliklerin çocuk ve gençlerde antisosyal davranışlara yönelime karşı koruma sağladığı belirtilmiştir (Jessor, Van Den Boss, Vanderryn, Costa ve Turbin, 1995). Öğretmenlerin de psikolojik sağlamlık konusunda eğitilmelerinin yararlı olacağı düşünülmektedir.

Son olarak, toplumsal boyutta sağlık kurumları, toplum ruh sağlı̆̆ merkezleri aracıllğıyla psikolojik sağlamlı̆̆ ve ilişkili yaşam becerilerini arttırmaya yönelik çalışmalar yapılmasının, farklı risk gruplarını hedef alan önleyici programlar geliştirilmesinin ve toplum ruh sağlı̆ıının, özellikle de psikolojik sağlamlığın ülke politikalarına dahil edilmesinin yararlı olacağı düşünülmektedir.

\section{Kaynakça}

Akar, A. (2018). Psikolojik sağlamlık programının ergenlerin psikolojik sağlamlık düzeyine etkisi. Doktora Tezi, Maltepe Üniversitesi, Sosyal Bilimler Enstitüsü, İstanbul. 
Akos, P., \& Galassi, J. P. (2008). Strength-based school counseling: Introduction to the special issue. Professional School Counceling, 12(2), 66-67. http://dx.doi.org/10.5330/PSC.n.201012.66

Albee, G. W., \& Ryan, K. (1998). An overview of primary prevention. Journal of Mental Health, 7:5, 441-449, DOI: 10.1080/09638239817824

Alvord, M. K., \& Grados, J.J. (2005). Enhancing resilience in children: A proactive approach. Professional Psychology: research and Practice, 36(3), 238-245, DOI: 10.1037/07357028.36.3.238

Barankin, T., \& Khanlou, N. (2007). Growing up resilient: Ways to build resilience in children and youth. Toronto. Centre for Addiction and Mental Health Publications.

Benard, B. (1991). Fostering resiliency in kids: protective factors in the family, school, and community. Portland, OR: Northwest Regional Educational Laboratory.

Benard, B. (1995). Fostering resilience in children. Educational Resources Information Center. (ERIC Document Reproduction Service No. ED386327).

Beyond Blue Ltd. (2017). Building resilience in children aged 0-12: A practice guide.

Black C. (2008). Working for a Healthier Tomorrow. London: The Stationary Office; 2008.

Botvin, G. J., \& Griffin, K. W. (2004). Life Skills Training: Empirical findings and future directons. The Journal of Primary Prevention, 25(2), 211-232.

Bradley, B., Whiteside, L., Mundfrom, D.J., Casey, P.H., Kelleher, K.J., \& Pope, S.K. (1994). Early indicators of resilience an their relation to experiences in the home environments of low birthweight, premature children living in poverty. Child Development. 65(2):346-360.

Brinkley, I, Fauth, R, Mahdon, M., Theodoropoulou, S. (2009). Is Knowledge Work Better For Us? Knowledge workers, good work and wellbeing. London: The Work Foundation, 2009.

Bronfenbrenner, U. (I 979). The ecology of human development: Experiments by nature and design. Cambridge, MA: Harvard University Press.

Brooks, R. B. (2013). The power of parenting. S. Goldstein \& R. B, (Ed.). Handbook of resilience in children içinde (pp. 443-458). New York: Springer Science+Business Media.

Brooks, R. B., \& Goldstein, S. (2001). Raising resilient children. Chicago: Contemporary Books.

Brown, K., \& Westaway, E. (2011). Agency, capacity, and resilience to environmental change: Lessons from human development, well-being, and disasters. Annual Review of Environment and Resourses, 36: 321-342. https://doi.org/10.1146/annurev-environ-052610-092905

Brunwasser, S. M., Gillham, J. E., \& Kim, E. S. (2009). A meta-analytic review of the Penn Resiliency Program's effect on depressive symptoms. Journal of Consulting and Clinical Psychology, 77(6), 1042-1054. http://dx.doi.org/10.1037/a0017671

Clauss- Ehlers, C.S., Weist, M. D. (2004). Introduction: Advancing community involment and planning to promote resilience in youth from diverse communities. C. S. Clauss-Ehlers \& M. D. Weist, (Ed.) Community Planning to Foster Resilience in Children içinde (pp. 3-12). New York: Springer Science+Business Media.

Condly, S. J. (2006). Resilience in children: A review of literature with implications for education. Urban Education, 41(3), 211-236. https://doi.org/10.1177/0042085906287902 
Conger, R. D., \& Conger, K. J. (2002). Resilience in Midwestern families: selected findings? From the first decade of a prospective, longitudinal study. Journal of Marriage \& Family, 64, 361373.

Criss, M. M., Pettit, G. S., Bates, J. E., Dodge, K. A., \& Lapp, A. L. (2002). Family adversity, positive peer relationship, and children's externalizing behavior: A longitudinal perspective on risk and resilience. Child Development, 73, 1220-1237.

De la Fuante, J., Zapata, L., Martinez-Vicente, J. M. Sanders, P., Crdelle-Elawar, M. (2015). The role of personel self- regulation and regulatory teaching to predict motivational-affective variables, achievement, and satisfaction; a structural model. Frontiers in Psychology, 6, 1-16.

Duckworth, A. L., \& Seligman, M. E. P. (2005). Self-discipline outdoes IQ in predicting academic performance of adolescents. Psychological Science, 16, 939-944. doi:10.1111/j.14679280.2005.01641.x

Eisenberg, N., \& Spinrad, T. L. (2004). Emotion-related regulation: Sharpening the definition. Child Development, 75, 334-339. https://doi.org/10.1111/j.1467-8624.2004.00674.x

Fleming, J., \& Ledogar, R. J. (2008). Resilience, an evolving concept: A review of literature relevant to aboriginal research. Pimatisiwin, 6(2), 7-23.

Fraser, M. W., Richman, J. M., \& Galinsky, M. J. (1999). Risk, protection and resilience: toward a conceptual framework for social work practice. Social Work Research, 23, 129-208.

Garmezy, N., Masten, A. S., \& Tellegen, A. (1984). The study of stress and competence in children: A building block for developmental psychopathology. Child Development, 55, 97-111.

Ginsburg, K.R. \& Jablow, M. M. (2006). A parent's guide to building resilience in children and teens: Giving kids roots and wings. Illinois: American Academy of Pediatrics.

Gürgan, U. (2006). Grupla psikolojik danışmanın üniversite öğrencilerinin yılmazlık düzeylerine etkisi. Yayımlanmamış doktora tezi, Ankara Üniversitesi Eğitim Bilimleri Enstitüsü, Ankara.

Hart, K. E. (1990). Introducing stress and stress management to managers. Journal of Managerial Psychology, 5(2), 9-16.

Hill, J., \& Hawk, K. (2000). Making a difference in the classroom: Effective teaching practice in low decile, multicultural schools. Wellington, New Zealand: Ministry of Education.

Jessor, R., Van Den Boss, J., Vanderryn, J., Costa, F.M., Turbin, M. S. (1995). Protective factors in adolescent problem behavior: Modetaror effects and developmental chnage. Developmental Psychology, 31, 932-933.

Kurtoğlu, Ş. (2013). Bilişsel davranışçı yaklaşıma dayalı psiko-eğitim programının ilköğretim birinci kademe öğrencilerinin duygusal yılmazlık, sosyal beceri, okula uyum ve benlik saygısı düzeylerine etkisi. Ege Üniversitesi, Sosyal Bilimler Enstitüsü, İzmir.

Lin, K. K., Sandler, I. N., Ayers, T. S., Wolchik, S. A., \& Luecken, L. J. (2004) Resilience in parentally bereaved children and adolescents seeking preventive services. Journal of Clinical Child and Adolescent Psychology, 33, 673-683.

Luthar, S. S., \& Cicchetti, D. (2000). The construct of resilience: Implications for interventions and social policies. Development and Psychopathology, 12, 857-885. 
Masten, A.S. (1994). Resilience in individual development: Successful adaptation despite risk and adversity. M.C. Wang, \& E.W. Gordon (Ed.), Educational resilience in inner-city America: Challenges and prospects içinde (pp. 3-25). Hillsdale, NJ: Lawrence Erlbaum AssocIates, Inc.

Masten A.S. (2001) Ordinary magic: Resilience processes in development. American Psychologist, $56,227-238$.

Masten, A. S. (2014). Ordinary magic: Resilience in development. New York: The Guilford Press.

Masten, A. S., \& Barnes, A. J. (2018). Resilience in children: Developmental perspectives. Children (Basel, Switzerland), 5(7), 98. doi:10.3390/children5070098

Masten, A.S., Best, K. M., \& Garmezy, N. (1990). Resilience and development: Contributions from the study of children who overcome adversity. Development and Psychopathology, 2, 425-444.

Masten, A. S., \& Coatsworth, J. D. (1998). The Development of competence in favorable and unfavorable environments: Lessons from research on successful children. American Psychologist, 53, 205-220.

Masten, A. S., Garmezy, N., Tellegen, A., Pellegrini, D. S., Larkin, K., \& Larsen, A. (1988). Competence and stress in school children: The moderating effects of individual and family qualities. Journal of Child Psychology and Psychiatry, 29, 745- 764.

Masten, A. S., Herbers, J. E., Cutuli, J. J., \& Lafavor, T. L. (2008). Promoting competence and resilience in the school context. Professional School Counseling, 12(2), 76-84.

Masten, A. S., Morison, P., Pellegrini, D., \& Tellegen, A. (1990). Competence under stress: risk and protective factors. J. Rolf, A. S. Masten, D. Cicchetti, K. H. Nuechterlein \& S. Weintraub, (Ed.) Risk and protective factors in the development of psychopathology içinde (pp. 236-257). New York: Cambridge University Press.

Masten, A. S., Obradovic, J. (2006). Competence and resilience in development. Annals of The New York Academy of Sciences, 1094: 13-27. https://doi.org/10.1196/annals.1376.003

Masten, A.S., \& Reed, M.G. (2002). Resilience in development. C. R. Snyder \& S. J. Lopez (Ed.), The handbook of positive psychology içinde (pp. 74-88). New York, NY: Oxford University Press.

McCubbin, M., Balling, K., Possin, P., Frierdich, S., Bryne, B. (2002). Family resiliency in childhood cancer. Family Relations, 51, 103-111.

McLaughlin, M., and Talbert, J. (1993). Contexts that matter for teaching and learning. Palo Alto, CA: Stanford University.

Prince-Embury, S. \& Saklofske, D. H. (2014). Building a science of resilience intervention for youth. S. Prince-Embury \& D.H. Saklofske, (Ed.) Resilience interventions for youth in diverse populations içinde (pp. 3-12). New York: Springer Science+Business Media.

Ringeisen, H., Henderson, K., \& Hoagwood, K. (2003). Context matters: Schools and the "Research to Practice Gap" in children's mental health. School Psychology Review, 32(2), 153-168.

Rutter, M. (1985). Resilience in the face of adversity: Protective factors and resistance to psychiatric disorder. British Journal of Psychiatry, 147, 598-611.

Seaman, P., McNeice, V., Yates, G., \& McLean, J. (2014). Resilience for public health: Supporting transformation in people and communities. Glasgow: Glasgow Centre for Population Health. 
Seligman, M. E. P., Ernst, R. M., Gillham, J., Reivich, K., \& Linkins, M. (2009). Positive education: Positive psychology and classroom interventions. Oxford Review of Education, 35(3), 293-311. doi: $10.1080 / 03054980902934563$

Seligman, M. E. P., \& Csikszentmihalyi, M. (2000). Positive Psychology: An introduction. American Psychologist, 55,5-14.

Smith Harvey, V. (2007). Schoolwide methods for fostering resiliency. https://www.nasponline.org/Documents/.../schoolresiliency.pd adresinden ulaş1labilir.

Theron, L., Liebenberg, L., \& Malindi, M., (2014). When schooling experiences are respectful of childrens rights: A pathway to resilience. School Psychology International, 35(3), 253-265.

Ungar, M. (2011). The social ecology of resilience: Addressing contextual and cultural ambiguity of a nascent construct. American Journal of Orthopsychiatry, 81(1), 1-17.

Ungar, M., Brown, M., Liebenberg, L., Othman, R., Kwong, W. M., Armstrong, M., \& Gilgun J. (2007). Unique pathways to resilience across cultures. Adolescence, 42(166), 287-310.

Ungar, M., Ghazinour. M., \& Richter. J. (2013). Annual research review: What is resilience within the social ecology of human development? Journal of Child Psychology and Psychiatry 54(4), 348-366 doi:10.1111/jcpp.12025

Ünüvar, A. (2012). Gerçeklik kuramına dayalı psiko-eğitim programının lise öğrencilerinin denetim odağı ve yılmazlık düzeyi üzerindeki etkisinin incelenmesi. Doktora Tezi, Dokuz Eylül Üniversitesi Eğitim Bilimleri Enstitüsü, İzmir.

Vohs, K. D., \& Baumeister, R. F. (2004). Understanding self-regulation: An introduction. R. F. Baumeister \& K. D. Vohs (Ed.), Handbook of self-regulation: Research, Theory, and Applications içinde (pp. 1-9). New York, The Guilford Press.

Waddell G, Burton A.K. (2006). Is work good for your health and well-being? London: The Stationery Office: 2006.

Werner, E. E. (1993). Risk, resilience, and recovery: Perpectives from the Kauai Longitudinal Study. Development and Psychopathology, 5, 503-515.

Werner, E. E. (1995). Resilience in development. Current Directions in Psychological Science, $4(3), 81-85$.

Winders, S. (2014). From extraordinary invulnerability to ordinary magic: A literature review of resilience. Journal of European Psychology Students, 5(1), 3-9.

Williams, J., Steen, S., Albert, T., Delley, B., Jacobs, B., Nagel, C., \& Irick, A. (2016). Academically resilient, low-income students' perspectives of how school counselors can meet their academic needs. Professional School Counseling, 19(1), 155-165.

Wright, M. O. D., \& Masten, A. S. (2015). Pathways to resilience in context. L. C. Theron, L. Liebenberg, \& M. Ungar, (Ed.) Youth resilience and culture içinde (pp. 3-22). Dordrecht: Springer Science+Business Media. 